\title{
The church in Africa and the struggle for an African identity 1
}

D Crafford

\section{ABSTRACT}

The church in Africa experienced a tremendous growth during the twentieth century but is still in search of a true African identity. How can the church, in a process of enculteration, remain genuinely African and genuinely biblical? The role of African Traditional Religion, African Theology and the African Independent Church in the search for identity is described. In the end an effor is made to answer the question how the identity crisis in Africa can be solved.

The church in Africa has experienced a miraculous growth during the twentieth century. Where in 1900 one in every 25 Africans was a Christian, in 2000 it will be one in every two Africans. Where in 1900 less than $4 \%$ of all Africans were Christians, in 2000 about $50 \%$ of the total population will be Christians. The following table based on statistics of D B Barrett in his World Christian Encyclopedia (OUP 1982) indicates the growth of Christianity in Africa from 1970 to the end of the century:

Number of Christians in millions

1980

2000

$\%$ of total population

203

400

$41 \% \quad 44,2 \%$

$50 \%$

By the year 2000 about $41 \%$ of Africa's population will be Muslims and about $8 \%$ adherents of African Traditional Religions. With a growth rate of about 4\%-5\% per annum Christianity increases with about 6,2 million people each year of whom 1,5 million people are new converts and 4,7 million are the result of natural increase.

Within African Christianity four major groups are represented which can roughly be divided as follows: Roman Catholic (40\%), Protestant (35\%), Independent African (19\%) and Eastern Orthodox (6\%). Of these groups the Protestant and Orthodox churches remain static or even decrease in membership while Roman Catholics grow steadily and the Independent Churches show a dynamic growth rate.

We can illustrate tendencies of growth by taking South African churches as an example. The following table is based on census figures from 1960 to 1991 . We select the five biggest denominations in South Africa with a total membership of more than one million. They are the following: Dutch Reformed Churches $(2,8$ 
million or $15 \%$ of the total population); Roman Catholic Church (2 million or $10,8 \%$ of the total population); Methodist Church (1,6 million or $8,7 \%$ of the total population); The Zion Christian Church (1,2 million or $6,5 \%$ of the total population) and the Anglican Churches (1,0 million or 5,6\% of the total population) ${ }^{2}$. The table shows the increase or decrease of these churches from 1960 to 1990 within the black population group of South Africa only as a percentage of the total black population ${ }^{3}$ :

\begin{tabular}{|lcccr|}
\hline Denomination & 1960 & 1970 & 1980 & 1991 \\
Roman Catholic & 6,25 & 8,97 & 9,9 & 12,2 \\
Methodist Church & 12,09 & 11,90 & 9,2 & 9,9 \\
Zion Christian Church & - & - & - & 9,7 \\
Dutch Reformed Church & 4,8 & 5,93 & 6,5 & 7,1 \\
Anglican Church & 6,89 & 6,40 & 4,8 & 4,6 \\
\hline
\end{tabular}

The above mentioned denominations are the biggest in South Africa but the Independent African Churches are by far the fastest growing and the biggest church family in the country. The following table illustrates this point clearly:

\begin{tabular}{|lcccc|}
\hline \multicolumn{5}{|c|}{ The growth of Independent Black Churches in South Africa } \\
Year & $\begin{array}{l}\text { \% of black } \\
\text { population }\end{array}$ & $\begin{array}{l}\text { Total } \\
\text { Membership }\end{array}$ & $\begin{array}{c}\text { Total black } \\
\text { population } \\
\text { in million }\end{array}$ & $\begin{array}{c}\text { \% of all } \\
\text { Christians }\end{array}$ \\
1948 & 9,6 & 761000 & 7,7 & - \\
1960 & 18,6 & 1594740 & 10,9 & 21 \\
1970 & $18,4^{*}$ & 2760000 & 15,8 & 18,3 \\
1980 & 27,3 & 5842000 & 21,4 & 36,3 \\
$1991^{* *}$ & 32,1 & 5770000 & $\pm 26,0$ & 46,8 \\
\hline
\end{tabular}

*The 1970 census figures are most probably not reliable. There must have been a much higher growth rate as reflected in the 1980 figures.

** The 1991 figures are provisional and based on only 17973000 black people who answered the questionnaire. Of this number 5,3 million or $29,7 \%$ did not fill in the question on religious affiliation. The percentages given are based on the 12,6 million who indicated their religious affiliation. 
From the figures above it is clear that Christianity as a whole but in particular the African Independent Churches expanded miraculously during the twentieth century. In spite of this miraculous growth, the Church in Africa has tremendous problems and challenges. One can mention the problem of nominalism and syncretism; the pluriform, divided and schismatic nature of African Christianity; the high degree of dependence on foreign assistance of the mission-connected churches; the great challenge of Islam and secularism; the difficult church-state relations in many countries; the many socio-economic problems of hunger, poverty, illiteracy, Aids, et cetera, facing the churches and finally the continuing tribalism and religious and political polarisation which lead to violence and disruption.

The Church in Africa must certainly pay attention to everyone of these challenges 4 . A key aspect in the life of the African church, that we want to explore briefly in this paper, is the struggle for an African identity which dominates the scene in post-colonial African Christianity. The outcome of this identity crisis will in the long run determine the future of African Christianity5. In this search for African identity, the Independent Churches play a major role. The question to answer is whether the Independent Churches have found a recipe for the inculturation of the Gospel in Africa? Is African Church and African theology that we find today genuinely African but in the same time genuinely biblical?

\section{THE ORIGIN OF THE IDENTTTY CRISIS}

Christianity was brought to Africa by Western missionaries who for most of the time had a very negative approach to African culture. In many cases they did not only reject elements of culture that contradicted biblical principles alone, but African culture in totality. In practice it meant that Africans, when becoming Christians, had to adhere to Western culture as well. The whole process of acculturation was intensified by the effects of colonial rule in Africa.

Western colonial rule and Western missions were experienced by many Africans as a form of aggression which bereaved them from their cultural inheritance. No wonder that when independence dawned for Africa in the sixties, a strong feeling of Black consciousness and African nationalism originated. The catch phrases of the time were "African personality", "negritude" and "black is beautiful". There was a strong revival of pride in African cultures. The result of this was a more positive evaluation of Traditional African Religions. Among Christians, the search for more authentic African expressions in practice and theology was stimulated. Many black theologians started to reflect on the relationship between faith and culture, and the Independent Black Churches as centers of inculturation, dramatically increased their membership numbers. 
According to John Mbiti the interaction in faith between Gospel and culture produces a particular brand of Christianity. This happened throughout the history of the expansion of Christianity and must also happen in Africa. "The only lasting form of Christianity in this continent, is that which results from a serious encounter of the Gospel with the indigenous African culture"6. An imported Christianity will never quench the spiritual thirst of African peoples. What is needed, is a Christianity that is truly "made in Africa". It is only within the cultural framework of Africa that Christianity can thrive, that the demands of the Gospel can be interpreted and that the message of Christ can fruitfully be propagated.

Most African theologians agree that a church can only be regarded as truly incarnated in Africa if it has practices, doctrines and symbols comprehensible to African people. Even an evangelical theologian like Byang $\mathrm{H}$ Kato emphasized the importance of contextualisation in liturgy, dress, language, music, symbols et cetera ${ }^{7}$. He warns, however, that contextualisation must never result in the acceptance of syncretism or universalism. He strongly rejects those African theologians who want to make Traditional Religion the most important source for African theology and then end up in a syncretistic form of Christianity. He is also worried about universalistic tendencies in the theology of John Mbiti and the great value that Bolaji Idowu ascribes to Traditional African Religions 8 . "The final challenge for the African Christian is to make Christianity culturally relevant while holding fast to its ever-abiding message" ${ }^{\text {"9 }}$. For Kato this means that African culture must be tested, judged and purified by Scripture and that the unique Lordship of Christ as presented in the Scriptures must never be denied.

\section{THE ROLE OF TRADITIONAL AFRICAN RELIGION}

Traditional religion is at the center of the African world view and therefore the central point of African culture. The question is how any part of African culture could be retained if Traditional Religion is rejected. If Africans accept Christianity, does it not automatically mean a radical break with nearly every element of traditional culture? This is the question with which many African theologians are struggling. Some feel that Traditional Religion should be regarded as a valid source for African theology. They accept a continuity between Traditional Religion and Christianity. They see Traditional Religion as a preparation for the Gospel. Many Western Protestant theologians again emphasized a discontinuity between Traditional Religion and the Gospel. For them the acceptance of the Gospel implies a total break with Traditional Religion and therefore also with traditional culture. 
The most acceptable position will perhaps be the acceptance of continuity and discontinuity. This means that there are elements in traditional culture that will be judged and rejected by the Gospel but that there are also areas of convergence which make the acceptance of the Gospel even easier for Africans.

Elements in Traditional culture which are incompatible with the Gospel are: the reign of terror of certain chiefs; cruelty during initiation ceremonies; low estimation of women; indifferent attitude towards people of other tribes; belief in sorcery, witches and magic and the role of the ancestors as mediators and protectors of the clan.

There are other religious elements that are not incompatible with the Bible. Such elements made it easier for Africans to understand the biblical message. The belief in a supreme Being who is creator and preserver of the universe, both immanent and transcendent, omnipresent, omniscient and omnipotent is not so far removed from the biblical view of God. As deus otiosus, the supreme Being is not particularly defined and Christian elements can easily be added to traditional ones. Another positive element is the holistic understanding of life and the view that religion is a way of life and not only a neglected element of it. More elements that are close to biblical thought can be mentioned: respect for authority; a sense of the numinous and awareness of the proximity of the spiritual reality; the communality and willingness to assist one another; emphasis on fundamental humanity and the wholeness of life; respect for values like hospitality, magnanimity, purity, truth and charitableness. The African disposition can thus help Africans to understand certain elements of the biblical message even better than Westerners. As an example one can mention the understanding of the concept of corporate personality and the importance of sharing the wholeness of life.

4 THE EMERGENCE OF AN AFRICAN THEOLOGY

The need for an African interpretation and application of the Gospel inspires African theologians to work hard to establish the origins, sources and method of African theology. They work on a new African hermeneutic in which the questions asked and the answers received from the word of God are relevant to the African situation and context. According to Fashole-Luke there are four major sources of African theology: African indigenous religion, the Bible, the practical experiences of African churches and lastly the theological heritage of Western churches ${ }^{10}$. The context and contours of African theology are described by Tite Tienou' ${ }^{11}$. Gwinyai Muzorewa emphasizes that such a theology must address the needs of people who are struggling to recuperate from a colonial mentality, from foreign economic, legal 
and political systems and in South Africa certainly also from an apartheid past ${ }^{12}$. It must be able to speak for the oppressed and marginalised but also to the soul of African people by making use of concepts of a traditional world view.

In the South African context the situation was experienced by Blacks as one of oppression and the liberation motif dominated the scene. Black theologians most naturally identified themselves with the poor, the marginalised and the oppressed. The liberation struggle was against apartheid which they regarded as irreconcilable with the Gospel of Christ. In this context Black theology emerged as a liberation theology with exponents like Alan Boesak, Desmond Tutu, Manas Buthelezi, Simon S Maimela and others. With our emphasis on the inculturation question, we cannot discuss the liberation branch of African theology but rather turn to a few African theologians who contributed towards an Africanisation of theology.

\subsection{Gwinyai Muzorewa}

Muzorewa can be regarded as a bridge figure between liberation theology and inculturation theology. He gives the following definition of African theology: "African theology is a reflective interpretation of what the biblical God is doing to enhance African survival through the agency of people who are informed by Scripture and traditional concepts of the God who is revealed to us through the faith and life of Jesus Christ"13. Although Muzorewa accepts traditional religion as a viable source for African theology, he also emphasizes strongly the fact that God is only fully and clearly revealed through Jesus Christ. He pleads for an African hermeneutical principle in which Scripture can be interpreted from the context of African culture and applied in a relevant way to the African context of poverty and suffering. The challenge is to be relevant for Africa but at the same time faithful to the message of the Gospel. Of such a theology salvation and liberation will be major ingredients. Christ is offering liberation "to the suffering, poor, ill, captive, hungry and naked bound in political, economic and social structures"14.

\section{$4.2 \quad J o h n$ S Mbiti}

Professor Mbiti, born in Kenya, educated in Uganda, the United States and England can be regarded as doyen of African theologians and one of the most prolific writers from Africa. He is from Anglican background. Mbiti defines African theology as "theological reflection and expression by African Christians"15. Mbiti regards the traditional religions of Africa as a preparation for the gospel and sees Christianity as a fulfillment of African religions. The God of the Bible was already known in Africa before the coming of Christianity. He stresses however, that African theology should keep close to the Scriptures in order to prevent syncretism and in order to 
maintain lasting links with the theology of the church universal. Mbiti is critical of South African and American black theology because of its one sided exaggeration of the theme of liberation while other important theological themes are neglected.

A number of Mbiti's important writings are African religions and philosophy (1970); Concepts of God in Africa (1970); New Testament eschatology in an African background (1971) and African and Asian contributions to contemporary theology (WCC 1977).

\subsection{Mercy Amba Oduyoye}

Professor Oduyoye is a native of Ghana and member of the Methodist Church. She studied theology in Ghana and at Cambridge and is a lecturer in the Department of Religious Studies at the University of Ibadan in Nigeria. She participated in the activities of the Ecumenical Association of Third World Theologians (EATWOT) and the Ecumenical Association of African Theologians (EAAT); was the first women to serve as president of the World Student Christian Federation; worked for the All Africa Conference of Churches and has also been Deputy General Secretary of the World Council of Churches. She wrote many articles on feminism and other theological themes. Her most well known work is: Hearing and Knowing. Theological Reflections on Christianity in Africa (Orbis 1986). According to Oduyoye "African theology is nothing less than the theological insights that Christians in Africa are bringing to Christian theology"16. She believes that African traditional beliefs and practices must be seriously considered by theologians. She refers to the belief in a spiritual world, to African communality, to the emphasis on the wholeness of the human being comprising soul and body and to the fact that Africans do not separate the sacred from the secular. Oduyoye believes that utilizing African religious beliefs can enrich Christianity to the benefit of all who adhere to it. This also counts for liturgical practices like drumming, dancing, extemporaneous prayer, traditional music, etc.

\subsection{Aylward Shorter}

Professor Shorter is a Roman Catholic priest, born in London, educated at Oxford and Rome and has taught in theological institutions in Uganda and Tanzania. He produced an extensive bibliography of which we mention a few titles: African Culture and the Christian church (Chapman 1973); African Christian Theology: Adaptation or Incarnation (Chapman 1975); African Christian spirituality (Orbis 1980); Jesus and the Witchdoctor (Chapman 1985) and Toward a theology of inculturation (Orbis 1988). Shorter is an eager exponent of "Inculturation theology" - a continuing interaction between Christian faith and culture. He pleads for a 
continuing exchange between Christianity and African Traditional Religions. He believes that African theology must grow out of continuing dialogue between Christianity and African Traditional Religion. He firmly believes that Africa can make a positive contribution to world Christianity: "The whole church is called upon to listen to the voice of African theologies - wholeness of life, symbolism, community"17. African Christian ideas must be translated in Western terms in order to enrich universal Christianity. "It is not enough to Africanize Christianity. African Christianity must discover a catholic vocation"18. Fashole-Luke is doubtful whether non-Africans like Shorter can write about African Theology ${ }^{19}$.

\subsection{Kofi Appiah-Kubi}

Kofi Appiah-Kubi is a lay theologian, born in Ghana and received theological training in Ghana, England and the United States. Appiah-Kubi is an eager exponent of a "theology of the people". Theology should concern itself with the poor, the sick, oppressed and dehumanised people. Theology must be lived out on the streets and thus practised by all Christians and not only by trained theologians. In his writings he pays much attention to healing and refers to traditional healing practices ${ }^{20}$. He feels positive towards the reverence for ancestors and applauds the way in which the Indigenous African Churches incorporate them into their communion and indigenise their worship and liturgies.

\subsection{Gabriel Molebe Setiloane}

Setiloane is the leading South African theologian who wrestles with the problem of the relationship between Christianity and Traditional African Religion. Other black theologians are more concerned with liberation than with traditional culture. Setiloane first qualified as a teacher and then entered the ministry of the Methodist Church of South Africa. He received theological training at Fort Hare, Rhodes University, Union Theological Seminary in the United States and at the Ecumenical Institute in Bossey, Switzerland and became a professor in the Department of Religious Studies at the University of Cape Town. In his doctoral thesis: The image of God among the Sotho-Tswana (1976) Setiloane made an analysis of the traditional beliefs of the Sotho-Tswana. In his African Theology, an introduction (1986) he put forward his views on the features and claims of African theology. For Setiloane the traditional God of the Sotho-Tswana, Modimo, is the source of life. He is Divinity present in the totality of creation and life. $\mathrm{He}$ is to be regarded as an ever active energy that permeates everything and initiate action. This belief of traditional Africans made it possible for them to accept the idea of the God of Christianity. According to Setiloane the missionaries planted the Gospel in the fertile soil of the 
traditional experience of Divinity. No religion can be cut of from the cultural roots of people. Therefore Christianity must also take root in the cultural context of Africa. As God revealed himself to the Hebrews as Jahweh, He is being revealed to Africans as Modimo, Thixo, Lesa et cetera ${ }^{21}$. The religious experiences of people of different cultures are however experiences of the one and only Divinity. This makes African Traditional Religion also a valid source for theology. If Modimo is the same as the God of the Bible, what happens with Jesus Christ? Setiloane answers: "African Theology sees the God of Jesus Christ ... as the same One and Only Source: Modimo, Qamata, Lesa, Umvelingangi of African Traditional Religion"22.

Setiloane clearly chooses for a monistic view of God as Divinity-energy and source of life. This is contradictory to the theistic view of a personal God who fully revealed Himself in Jesus Christ. For Setiloane the divinity of Christ is to be understood as ukuthwasa - the way in which a spirit or Divinity takes possession of a human being. This implies that the divine pre-existence of Christ cannot be accepted. He only became divine when the Spirit of God took possession of him. Setiloane gives the following definition of African theology: "It is an attempt to verbalise African reflection about Divinity (do theology) from the perspective of African grassroots, background and culture" 23 . The problem with this definition is that it makes Traditional Religion the primary source and the Bible a secondary one. In the end God of his theology is not God as revealed in the Bible but the God of Traditional Religion.

\section{THE EXPERIMENT OF THE AFRICAN INDEPENDENT CHURCHES}

The more than 5000 Independent Churches in Africa are an outgrowth of the desire for a more African and less Western expression of faith. They represent about a quarter of African Christians and make ample use of the African cultural and religious background. Like traditional Africans they have a pragmatic view of religion and are more interested in experiencing than formulating their religion. In these churches we have an experiment of theology in practice rather than theology in writing. In their effort to indigenise Christianity, the Independent Churches have developed their own church structures, liturgical forms, healing methods and ways of pastoral care. The reason for their unparalleled growth is because they speak a language and engage in practices intelligible to Africans.

The daily problems of witchcraft, sorcery and ancestor worship were in most cases ignored by Western missionaries. This deficiency led to the rise of Independent Churches. They believe in the reality of witchcraft and evil spirits but at the same time confront them very efficiently. This means that the Independents 
do not really accommodate Traditional Religion but confront it in many ways. According to Schoffeleers this is the big difference between African theology and the theology of the Independent Churches ${ }^{24}$. When African theology uses Traditional Religion uncritically as a source for theologising, the danger is real that central truths of the Bible may be lost. On the other hand, the Independent Churches in their effort to express faith practically in terms of African culture, can easily fall back into syncretism. Only in a qualified way can African theology be regarded as the academic version of the faith of Spirit Churches. The two need to complement each other. The Independent Churches must teach African theology how to critically confront Traditional Religion. African theology on the other hand must help Independent churches to avoid syncritism.

J B Ngubane points out that the Independent Churches and Black theology also stand in a complementary relationship. Zionist theology is strong in the spiritual and vertical dimension while Black theology is strong in the secular and horizontal dimension. Black theology must help the Independents to develop a political awareness and Zionists should teach Black theology the secrets of deeper spiritual faith ${ }^{25}$.

African Independent Churches can no longer be regarded as bridges back to Traditional Religion. They must rather be seen as churches in making, as bridges to the future for a truly indigenised Christianity in Africa ${ }^{26}$. They are on their way to future forms of African Christianity. On this way they need help and support of established churches. They do not need help that will let them lose their independence but theological training and inspiration that will help them to be part of the universal church.

The question is how to reconcile African authenticity with biblical authenticity? How can a particular African Church remain part of the universal body of Christ? How can a particular African theology enrich the universal Christian theology? Christianity is changing African culture, but will the cultural revolution in Africa in its pursuit of authenticity and identity not change Christianity?

If a large part of African Christianity should be changed into either a syncretistic structure or into a body serving tribal gods instead of the true God, it would be a tragedy for world Christianity. But if Christianity could find a new identity in the African context, become a place for African Christians to feel at home, speak a language that appeals to Africans and still remain true to the essentials of the gospel, it will be nothing less than a miracle of God's power to evangelize the cultures of humankind. It will show the ability of Christianity to adapt itself to any culture 27 . Inculturation implies that cultural values must be 
judged in the light of the gospel. Certain values could be retained. But if the "kernel" or focus point of a culture is being infiltrated by the gospel, a process of cultural Christianisation must inevitably take place and many traditional values and practices will have to be replaced by Christian ones. This process will have to be completed by African theologians themselves.

The crux of the matter is: what is the right relationship between gospel and culture. Andrew Walls speaks of the gospel as both prisoner and liberator of culture. It is prisoner in as far as it cannot be separated from a specific culture. The incarnation of Christ sets the example for the gospel to be incarnated into any culture. Walls calls this aspect the "indigenizing principle". On the other hand the gospel is also liberator because it has to set culture free from demonic and sinful elements in it. This is what Walls calls the "pilgrim principle". To be true to Christ every Christian must also be critical of his own culture. Any particular church must see to it that it remains en route with Christ and the universal body of Christ in order to fulfill Gods purpose with His world. This is the universalizing aspect of Christianity which will assure that Christians from a diversity of cultures will still belong to each other and to the one body of $\mathrm{Christ}^{28}$.

The church in Africa will also have to find a balance between the desire to indigenise and the need to continue moving towards Christ as a pilgrim body in the world. In this connection Joel B Kailing points out that if the indigenising principle operates alone, it will bring a church into isolation and lead it astray into separation from the universal church. It must always operate in balanced tension with the pilgrim principle which is continually tugging the church towards the universals of faith. This principle can only work if churches live together in ecumenical interdependence ${ }^{29}$.

This implies that the Church in Africa must not in its effort to indigenise, isolate itself from world Christianity. Only a continuing dialogue between African and Western theologies can help both to enrich each other. The universal body of Christ must help the particular members of it not to depart from the universal truths of the Christian faith. For this reason African churches and Western churches need each other. In the same way African Theology, Black Theology, Western Theology and Asian Theology need each other in order to discover together the full richness of the revelation of God in Christ and through the Holy Spirit.

\section{NOTES:}

$1 \quad$ Paper read at a symposium on "Serving the Independent Churches", August 1992 and published with the permission of the Center for Theology and Service, Hammanskraal.

2 J J Kritzinger, "Godsdienstige samestelling in die RSA", ISWEN 
Kommunikasie 14/1 (1992), 10.

3 J J Kritzinger, idem, 11.

4 V Mertens, "Africa: the challenge of a young and dynamic church", Worldmission 32/3 (1981), 4-13.

$5 \quad$ Ngoni Sengwe, "Identity crisis in the African Church", Evangelical Missions Quarterly 17/2 (1981), 92-99.

6 John S Mbiti, "Christianity and African Culture" Journal of Theology for Southerm Africa 20 (1977), 30.

7 Byang H Kato, Biblical Christianity in Africa, a collection of papers and addresses, African Christian Press, Achimota 1985.

$8 \quad$ Kato, $a w, 30$.

$9 \quad$ Kato, $a w, 31$.

10 E W Fasholé-Luke, "Footpaths and signposts to African Christian Theologies", Scottish Journal of Theology 34/5 (1981), 407.

11 Tienou Tite, "Indigenous African Christian Theologies. The uphillroad", International Bulletin of Missionary Research 14/1 (1990), 73-77.

12 Gwinyai Muzorewa, "A definition of a future African Theology", Africa Theological Journal 19/2 (1990), 168.

13 Muzorewa, $a w, 174$.

14 Muzorewa, $a w, 177$.

15 John S Mbiti, "The Biblical basis for present trends in African Theology", Occasional Bulletin of Missionary Research July 1980, 119.

16 Mercy Amba Odudoye, Hearing and Knowing. Theological reflections on Christianity in Africa, New York 1986, 76.

17 F Burton Nelson, "New frontiers in African Theology", Evangelical Review of Theology 14/1 (1990), 221.

18 Aylward Shorter, African Christian Theology. Adaptation or Incamation, London 1975, 23.

19 Fasholé Luke, $a w, 391$.

20 Kofi Appiah-Kubi, Psychology, religion and healing, Ghana University Press, 1979; The Church's Healing Ministry in Africa, Contact 29, WCC, Geneva 1975.

21 G M Setiloane, African Theology. An introduction, Johannesburg 1986, 32. 
22 Idem.

23 Setiloane, $a w, 35$.

24 M Schoffeleers, "Black and African Theology in Southern Africa: a controversy re-examined", Journal of Religion in Africa 18/2 (1988), 113.

25 J B Ngubane, "Theological roots of the African Independent Churches and their challenge to Black Theology", in: I J Mosala and B Thlagale, The Unquestionable right to be free: Essays in Black Theology, Johannesburg 1986, 71-90.

26 J B Kailing, "Inside outside, upside down: in relationship with African Independent Churches", International Review of Mission 77/305 (1988), 38-52.

27 D Crafford, "African Christianity: a miracle or a tragedy", Africa Insight 12/3 (1982), 158.

28 Andrew Walls, "The Gospel as prisoner and liberator of culture", Missionalia 10/3 (1982), 97.

$29 \quad$ Kailing, $a w, 54$. 